\title{
A case for increased private sector involvement in Ireland's national animal health services
}

\author{
Simon J. More \\ Centre for Veterinary Epidemiology and Risk Analysis \\ UCD School of Agriculture, Food Science and Veterinary Medicine \\ University College Dublin \\ Belfield, Dublin 4, Ireland \\ Email: Simon.More@ucd.ie
}

Non-regulatory animal health issues, such as Johne's disease, infectious bovine rhinotracheitis (IBR) and mastitis will become increasing important, with ongoing globalisation of markets in animals and animal products. In response, Ireland may need to broaden the scope of its national animal health services. However, there have been concerns about the respective roles and responsibilities (both financial and otherwise) of government and industry in any such moves. This paper argues the case for increased private sector involvement in Ireland's national animal health services, based both on theoretical considerations and country case studies (the Netherlands and Australia). The Dutch and Australian case studies present examples of successful partnerships between government and industry, including systems and processes to address non-regulatory animal health issues. In each case, the roles and responsibilities of government are clear, as are the principles underpinning government involvement. Furthermore, the roles and responsibilities (financial and otherwise) of the Dutch and Australian industry are determined through enabling legislation, providing both legitimacy and accountability. There are constraints on the use of EU and national government funds to support non-regulatory animal health services in EU member states (such as Ireland and the Netherlands).

Irish Veterinary Journal

Key words: animal, funding, health, industry, veterinary Volume 61 Number 292-100, 2008

\section{Introduction}

The quality and safety of Irish agricultural product will become increasingly important, if Ireland is to remain competitive in a global trading environment. Animal health is an important contributor to on-farm profitability,

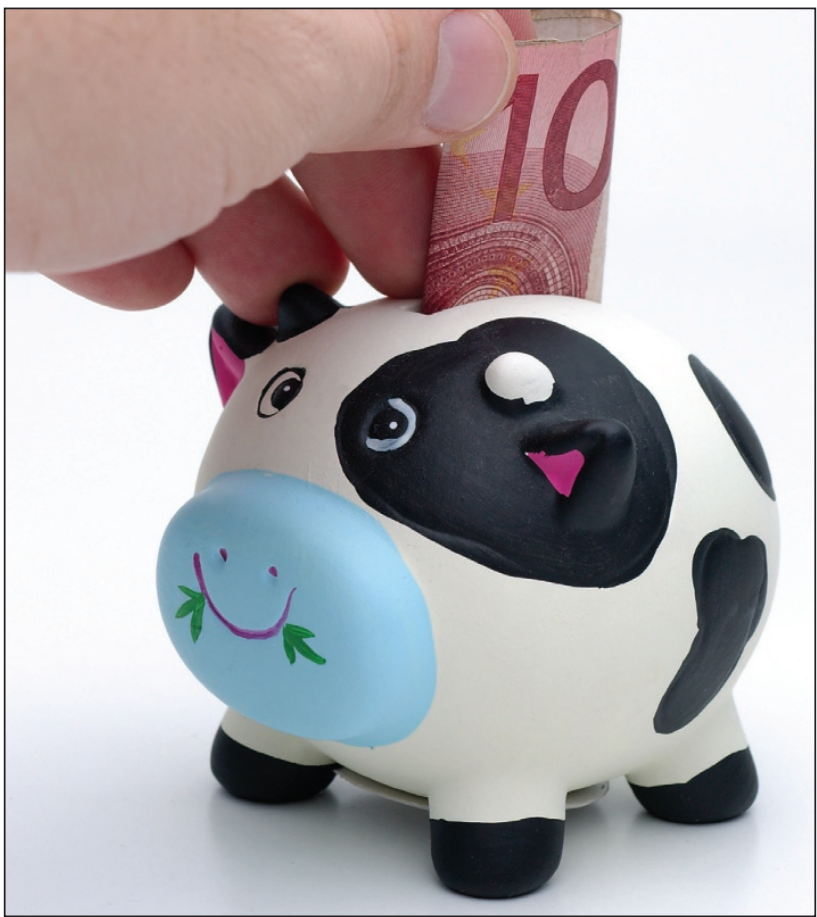

This paper argues the case for increased private sector involvement, including funding, in Ireland's national animal health services. as well as food quality and safety, and the international competitiveness of livestock and livestock products. The health status of the national herd, now and into the future, is an important issue for consideration.

Animal health services have both local and national components. This paper specifically focuses on national animal health services, which encompasses the systems (including organisations and infrastructure) and processes (for example, policy development, programme formulation and delivery) that facilitate national coordination of efforts towards improved animal health in the national herd.

In the past 12 months, there has been growing interest in the work of Ireland's national animal health services (McCarthy, 2007; More, 2007). In particular, it has been suggested that the scope of this work be expanded, to address a range of non-regulatory animal health issues, including Johne's disease, infectious bovine rhinotracheitis (IBR) and mastitis. However, as part of this discussion, there has been concern from within both government and industry as to the respective roles and responsibilities (both financial and otherwise) of government and industry in any such moves. Drawing on theoretical considerations and country case studies (from Ireland, the Netherlands and Australia), this paper argues the case for increased private sector involvement in Ireland's national animal health services. The Netherlands and Australia, like Ireland, are each heavily reliant upon the 
export of livestock and livestock products. Ireland and the Netherlands operate within the protections and constraints afforded by the European Union, whereas Australia does not.

\section{Public and private sector involvement in national animal health services: theoretical considerations}

\section{a. Criteria for public and private sector involvement}

Public funds are finite, and governments need objective criteria to enable the equitable and appropriate allocation of these funds. Generally, these criteria are based on the concept that public funds are used to support public goods and services (Umali et al., 1994), but not those of a private nature. Public goods and services (for example, national institutions for law and order, public roads, education, hospitals etc.) are generally funded through compulsory taxation and are, therefore, available to all. In economic terms, public and private goods are distinguished using the principles of excludability and rivalry. Purely public goods are those goods from which it is not possible to exclude one consumer without excluding all (non-excludability) and of which the consumption by one person does not reduce its availability for consumption by others (non-rivalry) (Ahuja, 2004). Conversely, purely private goods are fully excludable and rivalrous. Some goods and services lie between these extremes; in particular, goods and services with externalities (or spillover effects) (Umali et al., 1994).

The concepts of public and private good are applicable to animal health services, since each service can be classified according to its economic character (Umali et al., 1994). Using these criteria, several authors have defined public and private sector roles in the provision of animal health services (Holden, 1999; Ahuja, 2004). As an illustration, veterinary epidemiological services are primarily considered a public good (the information provided is of benefit to the community, and cannot be appropriated by a single individual), whereas diagnostic services may provide elements of both private and public good, depending on the degree to which externalities are produced (Umali et al., 1994). A national mastitis programme has the potential to provide benefits to dairy farmers and processors, but with limited additional benefits to the broader human population. Therefore, this programme would primarily be considered a private (or industry) good.

It is widely accepted that the public and private sectors each have a role to play in improving animal health (Ekboir, 1999; Holden 1999; Sen and Chander, 2003). However, there is considerable debate about the balance between the two (Ekboir, 1999). In a recent submission to DG Sanco, the Swedish Ministry of Agriculture, Food and Consumer Affairs suggested that public measures should be limited to animal diseases with public health risks, an environmental dimension and/or symptoms similar to dangerous animal disease, diseases that are highly contagious, diseases where knowledge is lacking and diseases that can be widely spread without detection (Anon., 2006a). Similarly, Ekboir (1999) suggested that public intervention in the development and implementation of animal health policies should be guided by:

- Whether the targeted disease can affect humans;

- Its degree of contagiousness;

- Whether it is endemic or epidemic; and,

- The economic costs associated with the disease. Bicknell et al. (1999) highlight issues faced by a centralised animal health service (the Animal Health Board, responsible for the control of bovine tuberculosis in New Zealand) within a market-oriented economy; in particular, identification and implementation of policies to simultaneously encourage farmer participation and increased cost-recovery. Prompted in part by the rising costs associated with TB control, 'responsibility- and costsharing' is an increasingly important issue in the United Kingdom (Anon., 2007a). Several authors have examined factors relevant to the transition from an exclusively-public model of veterinary services, with primary emphasis on the developing world (Schillhorn and de Haan, 1995; Sen and Chander, 2003; Brückner, 2004; Leonard, 2004).

Although efforts towards privatisation are being made (Sen and Chander, 2003), the national animal health services in many developing countries remain essentially a government responsibility (Schillhorn and de Haan, 1995). In most developed countries, however, the allocation of public funds is increasingly guided by the principle of 'who benefits, pays'. Using this approach, benefit flowing primarily to industry is distinguished from the broader public benefit. As a result, animal health services in developed countries are increasingly performed in partnership with, or have been transferred to, the private sector (Umali et al., 1994).

\section{b. Models of public and private sector involvement}

National animal health services have frequently been regulated by government using the 'command and control' approach (Baldwin and Cave, 1999). The bovine tuberculosis control programme in Ireland is an example of this. Characteristics of this approach to governance (the rules, processes and behaviour that affect the way in which powers are exercised; Anon., 2004a) and regulation (primary and secondary legislation of government, rules and regulations of self-regulating bodies; Anon., 2004a) include 'legal bindingness', a rigid approach to implementation, predominantly public actors in policymaking and a central locus of authority (Treib et al., 2007). However, this approach has a number of inherent weaknesses, including the potential for undue influence (regulatory capture) by the regulated on the regulator, a tendency towards excessive legalism (a proliferation of unnecessarily complex and inflexible rules), creative compliance (the practice of avoiding the intention of a law without breaking its terms; Knill and Lenschow, 2003) and 
the problems (including cost) of enforcement (Baldwin and Cave, 1999).

Government involvement in national animal health services need not equate to government control. There are many possible models of governance and regulation, ranging from government intervention (such as the 'command and control' model) through to societal autonomy (Treib et al., 2007). In some governance and regulation models, government plays no role (Egan, 2001). The 'open method of communication' (OMC) of the EU is one example of an alternative governance and regulation model (Knill and Lenschow, 2003), a second is co-management of natural resources (Pomeroy and Berkes, 1997; Carlsson and Berkes, 2005), and a third is self-regulation (Baldwin and Cave, 1999). The OMC is a relatively new form of governance that relies on the voluntary cooperation of EU member states. Using 'soft law' rather than treaty-based legislation, the OMC involves:

- Guidelines and indicators: policy guidelines for the EU as a whole, with short, medium and long term goals;

- Benchmarking: quantitative and qualitative indicators for benchmarking national performance against the best in the world; and,

- Sharing of best-practice: periodic monitoring, evaluation and peer review of member states (Room, 2005).

In Ireland, 'social partnership' is one example of an inclusive partnership-based approach by the public and private sectors to governance and regulation (Anon., 2007b). The national agreements, first introduced in 1987, have been an important contributor to Ireland's recent economic success (Hardiman, 2002). The farming community has been one of the social partners in each national agreement (Anon., 2007b).

\section{Public and private sector involvement in national animal health services: case studies}

\section{a. Ireland}

In Ireland to this point, national animal health services have been a government responsibility, through the Department of Agriculture, Fisheries and Food (DAFF). DAFF implements EU policy and has responsibility for international trade, field operations, list A diseases and public health. It manages several disease eradication programmes, including bovine tuberculosis (More and Good, 2006), bovine brucellosis (Sheahan et al., 2006) and bovine spongiform encephalopathy (Sheridan et al., 2005). The role of industry in policy development and the enforcement of EU regulation etc. is limited. Farmers contribute financially to the bovine and tuberculosis eradication programmes through compulsory disease levies (€0.0006 per litre of milk processed and $€ 1.27$ per animal slaughtered or exported alive; Anon., 2006b), equivalent to $€ 210$ per typical Irish dairy farm (70 cows, annual production 5,000 litre per cow) or approx. €3.2 million from the national dairy farming sector. Each farmer also pays for the private veterinary costs associated with one whole-herd tuberculin test each year. National laboratory support is provided through DAFF's Veterinary Laboratory Service, which operates one central research and six regional laboratories. Farmers pay for nonregulatory diagnostic work. Ireland's national animal health services have some input into non-regulatory diseases of cattle and sheep (such as Johne's disease, IBR and mastitis). Teagasc (the Irish Agriculture and Food Development Authority) provides advisory and research support for mastitis and fertility. In collaboration with the pig and poultry industries, government is coordinating a national Aujeszky's disease control and eradication programme and enhanced Salmonella control through the Egg Quality Assurance Scheme, respectively.

Limited funding is available to support applied animal health research in Ireland, from both government and industry. The Research Stimulus Fund Programme supports 'public good' agri-production related research, using National Development Plan (2007-2013) funding. Industry provides support to Teagasc's dairy research programme through the voluntary dairy research levy (€1.2 million in 2004) (McGuinness, 2004). This programme predominantly focuses on production, rather than health, issues.

There are a large number of industry organisations in Ireland representing farmers (e.g., Irish Farmers Association, Irish Creameries Milk Suppliers Association, Irish Cattle and Sheep Farmers' Association), cooperatives (e.g., Irish Cooperative Organisation Society) and commodity-related businesses (e.g., Irish Dairy Industries Association). Further, national organisations are in place for product promotion, both nationally (e.g., National Dairy Council) and internationally (e.g., Irish Dairy Board).

\section{b. The Netherlands}

In the Netherlands, national animal health services are best understood by first considering the concept of product boards. Product boards (also known as commodity and industrial boards) were first established to contribute to post-war reconstruction, based on the principle that added value could be achieved through collective effort. Each product board operates under national legislation within a legal framework of a 'statutory trade organisation', and is authorised by government to formulate statutory rules in specific areas. They have the legal authority to establish regulations and impose levies, but are not government agencies. Each board acts in the interest of their sector as a whole and of society in general, adding value by raising standards in industry, addressing sectorwide issues, improving working conditions, providing an alternative to government regulation, providing linkages with government, ensuring market transparency and encouraging innovation (Anon., 2004b). There are national commodity boards for primary production, including milk (Productschap Zuivel, PZ; the Dutch Dairy Board) and 
livestock, meat and eggs (Productschappen Vee, Vlees en Eieren, PVE) and industrial boards in manufacturing, trade and logistics. Within each sector of primary production, the product board covers all relevant trade and product activities, from farmyard through to retail.

Established in 1956, the Dutch Dairy Board is a vertical organisation, incorporating bodies that represent dairy farmers, the dairy industry, traders, retail and trade unions. It also has close links with specialist organisations that provide services in animal health (GD Animal Health Service Deventer) and in milk quality assurance and control. With a workforce of approx. 100 people, the Dutch Dairy Board coordinates all national activities relating to the industry, including national dairy policy, international trade regulations (import and export) and sector regulations (quota, superlevy, milk premia). The organisation is financed through levies and payments. In 2007, levies of approx. $€ 18$ million were collected from dairy farmers (47\%; $€ 8.5$ million in total), on-farm processors $(1 \%)$ and the dairy processing industry $(52 \%)$ and used to finance activities relating to research (dairy products, 26\%; dairy farming, 31\%), information and communication (25\%) and cattle healthcare (18\%). The Board is also reimbursed by the government for operating costs associated with implementation of European market regulations (approx. $€ 7.2$ million in 2007) (Anon., 2007c).

GD Animal Health Service is the primary provider of non-regulatory animal health services in the Netherlands. Initially founded by and for farmers in 1919, GD is now an autonomous and independent operating enterprise. During 2005, GD had a turnover of 47.1 million, and a staff of 420 (full-time equivalent) (Anon., 2005a). GD is highly respected internationally, particularly in the areas of animal health diagnostics, animal health programmes and animal disease monitoring. Through the activities of GD, the Netherlands is leading international efforts in the implementation of voluntary animal health programmes (such as Johne's disease; Kalis et al., 2004; Weber et al., 2006). GD is coordinating Uier Gezondheids Centrum Nederland (UGCN; the Dutch Udder Health Centre), a national five-year programme to decrease mastitis incidence. This work is funded by the Dutch Dairy Board, and coordinated by GD under a steering committee, comprising farmers (Dutch Organisation for Agriculture and Horticulture; LTO, Land-en Tuinbouw Organisatie Nederland), industry (Dutch Dairy Association; NZO, De Nederlandse Zuivel Organisatie) and the Dutch Dairy Board.

The contribution of the Dutch government to national animal health services is essentially limited to activities in fulfillment of EU and international regulatory obligations. This work is coordinated through the national Ministry of Agriculture, Nature and Food Quality (LNV; Landbouw, Natuur en Voedselkwaliteit). The Food and Consumer Product Safety Agency (VWA), an independent agency of LNV, has a range of responsibilities including notifiable animal disease control, export certification, regulatory control of the meat sectors, and oversight of the work of the Netherlands Controlling Authority for Milk and Milk Products (COKZ) (Anon., 2006c). Since mid-2007, COKZ has formed part of Qlip (Kwaliteitsborging in de Zuivelketen), the central organisation for quality assurance in the Dutch dairy sector (Anon., 2007d). In the area of notifiable disease control, VWA works closely with other organisations including the Central Institute for Animal Disease Control (CIDC-Lelystad, the national reference laboratory) and GD Animal Health Service. Testing for export certification is conducted by both CIDC-Lelystad and other laboratories, such as GD Animal Health Service.

Cost-sharing is a key principle underpinning the funding of animal health services in the Netherlands. In a recent position paper, the ministry stated that "farmers and others who create income (from) animals... must make a substantial contribution to the costs incurred by government for the monitoring and control of animal diseases" (Anon., 2006d). Given its contribution to both public and private good, animal disease surveillance activities are funded $50 \%$ each by government and industry. In contrast, non-regulatory animal health issues are considered the sole responsibility of industry. At times, government does provide some contribution to the development of new non-regulatory animal health programmes, however, in all cases these contributions is restricted to defined projects, and used to support innovation (as opposed to operations). On-farm costs relating to voluntary animal health programmes, including the cost of sample collection and laboratory testing, are borne by individual farmers. Although financial details are commercial-in-confidence (confidential information), the operating model of GD Animal Health Service is essentially full cost-recovery.

\section{c. Australia}

Government is responsible for defined aspects of the national animal health services in Australia. The federal government (through the national Department of Agriculture, Fisheries and Forestry) has responsibility for quarantine, international animal health matters and the formulation and coordination of national policy. The Australian Quarantine and Inspection Service (AQIS), as part of the Department of Agriculture, Fisheries and Forestry, is responsible for the delivery of quarantine import requirements and export health certification. Most aspects of this service are operated on a full cost-recovery basis. State and territory governments are responsible for disease control, surveillance and eradication within their own borders. Consultative committees ensure that these bodies work together (Anon., 2006e).

Industry plays a key role in many aspects of the national animal health services, either through industry/government partnership bodies (e.g., Animal Health Australia) or essentially independent of government (e.g., Dairy Australia). 
Animal Health Australia (AHA) is a not-for-profit public company established in 1996 by the federal, state and territory governments and major national livestock industry organisations. It is a key contributor to national policies in animal health, and in the facilitation of partnerships between government and industry. Through AHA, the livestock industries participate in national policy development, provide substantial financial support to targeted activities and contribute to emergency responses (Anon., 2006e). Currently, AHA services runs eight major programme areas, including animal disease surveillance, emergency animal disease preparedness, animal health services, special programmes, Johne's disease control programmes and training. As part of emergency disease preparedness, AHA has developed detailed contingency plans (AUSVETPLANs) focusing on disease strategies, as well as operational, enterprise and management manuals. Further, an Emergency Animal Disease (EAD) Response Agreement was negotiated between government and industry in 2001, clearly defining obligations (financial and otherwise) in the event of an exotic disease outbreak. EADs are classified according to their impacts on human health, the environment and livestock industries (trade losses, national market disruption, production losses) and costsharing (covering salaries and wages, operating expenses, capital costs and compensation) varies accordingly.

AHA's industry partners include a range of national producer-owned industry organisations (for example, Australian Pork Limited, Dairy Australia and Meat and Livestock Australia). These organisations operate under national legislation, and have a broad range of responsibilities including marketing, export development, research, innovation and strategic policy development. For example, the goal of Dairy Australia is:

"to deliver the services needed by the Australian dairy industry for its ongoing and future development as a competitive, innovative and sustainable dairy industry that contributes to the overall prosperity of Australian and regional economies." Each organisation is managed by industry, and owned by its members (farmers and industry bodies). The organisations are subject to periodic independent review (Hassall and Associates, 2006). They are primarily supported by industry levies, which are collected under national legislation by the Levies Revenue Service. During 2005/06, AUD32.3 million (approx. €19.4 million; based on AUD0.026448 per kg fat plus AUD0.064438 per kg protein) was collected from dairy farmers, to support Dairy Australia, including its contribution to AHA's animal health programmes. This is equivalent to AUD1,194 (approx. €714) per typical Irish dairy farm (70 cows, annual production 5,000 litre per cow, average $3.4 \%$ fat and $3.9 \%$ protein). Similarly, approx. AUD81 million (based on AUD5.00 per head [grass and feedlot cattle], AUD0.90 per head [bobby calves], $2 \%$ of sale price to a max. AUD0.20 for sheep and AUD1.50 for prime lambs, AUD0.377 per head [goats]) was collected in transaction levies from beef and sheep producers in 2005/06 to fund
Meat and Livestock Australia, including its contribution to AHA's animal health programmes. On January 1, 2006, the cattle transaction levy was raised from AUD3.50 to AUD5.00 per head. This decision was taken by the beef industry, based on an assessment of future programmes and funding needs (Anon., 2005b) and following a ballot (with $57.7 \%$ in favour) of its members. Levies are recognised as an effective mechanism to pool effort and resource thereby enabling industries to collectively address priority issues.

The genesis of current national structures for animal health services in Australia, and particularly the key role of industry, can be traced back to 1983 (Lehane, 1996). To this point, the national Brucellosis and Tuberculosis Eradication Campaign (BTEC) had progressed smoothly in southern Australia, and a number of areas had achieved disease freedom. By 1983, eradication efforts were increasingly focused on northern Australia. In these areas, however, there were limited facilities for cattle management, and eradication efforts were greatly hampered by difficulties associated with the clean (complete) muster of cattle from many outback properties. To progress eradication, key decisions were made by the central (Canberra-based) technical committee which raised increasing concern among northern producers. Indeed, at the time, Lehane (1996) recalls comments in one newspaper:

"Cattlemen fear for their future as the bureaucrats ride in. Right across northern Australia... there is a galloping sense of fear at the looming prospect of the destruction of the northern cattle industry."

The national stalemate that ensued was eventually resolved following the decision of the national Minister of Primary Industries, who indicated that programme management would be based on equal representation from industry and government. From that point, the roles and responsibilities (both financial and otherwise) were shared and clearly defined for both industry and government. In a recent review, Radunz (2006) suggested that the involvement of industry in both funding and policy development was seen as a critical factor in the eventual success in this programme. Similarly, Whittem (1998) highlighted the key role of industry leadership in the financing and oversight of the program, suggesting that it was a sine qua non for its success.

\section{The performance of the national animal health services}

\section{a. Regulatory animal health issues}

The export of animals and/or animal products is a critical contributor to the national economies of Ireland, the Netherlands and Australia. In 2005, these countries were the fifth, third and first largest international beef exporters, and the fourth, second and eighth largest butter exporters, by value, respectively (International Trade Centre UNCTAD/WTO, 2005). International regulatory 
obligations (in the case of Ireland and the Netherlands, also EU obligations) are fundamental to unhindered international trade and a central priority for the national animal health services in each country. Given this background, there are many examples among each of the national services of international leadership and research innovation in the area of regulatory animal health (Bouma et al., 2003; More et al., 2006; Martin et al., 2007a,b). Under international and EU legislation, government is considered the competent central authority, and these activities must be conducted by government, or under its direction. In Ireland, this work is funded primarily by government. In contrast, in both Australia and the Netherlands, industry contributes to (in some circumstances covers the full cost of) government regulatory activities (e.g., surveillance in the Netherlands, quarantine and inspection in Australia).

\section{b. Non-regulatory animal health issues}

The Netherlands and Australia are each making rapid progress in addressing a range of issues concerning nonregulatory animal health. The national mastitis and Johne's disease programmes in the Netherlands and Australia, and the InCalf (fertility) programme in Australia, are each considered international leaders, and each is effectively translating knowledge into substantial progress on the ground.

Progress in non-regulatory animal health issues in Ireland is limited to the pig and poultry sectors, through the Aujeszky's and enhanced salmonellosis control programmes, respectively. In the cattle and sheep industries, equivalent programmes have not been established.

\section{Addressing non-regulatory animal health issues: potential lessons from the Netherlands and Australia}

The above-mentioned discussion highlights limitations with the scope, but not the quality, of Ireland's national animal health services. In those areas within the current remit of the Irish animal health services (that is, regulatory animal health), Ireland's progress is not dissimilar to that achieved in comparable countries. However, it will be in Ireland's long-term interest to broaden the scope of these services, given the increasing impact of non-regulatory animal health issues in global trade (More, 2007). In both Australia and the Netherlands, this gap has been addressed through a very substantial increase in industry involvement in the national animal health services. I contend that similar moves are needed here.

\section{a. Public sector involvement}

In both the Netherlands and Australia, the allocation of public funds in the national animal health services is guided by the principle of 'who benefits, pays'. The Dutch position is reflected in a recent position paper (Anon., 2006d), where the authors argue that government funding for disease control should be considered on a sliding scale: "the greater the external effects on monitoring and control, the greater the justification for government involvement (direct and financial)." In this situation, 'external effects' can be equated with 'public good'. Australia has reached almost identical conclusions, as reflected in the cost-sharing arrangement between government and livestock industry within the Emergency Animal Disease Response Agreement (Figure 1). Industry bodies also reflect a clear commitment to the

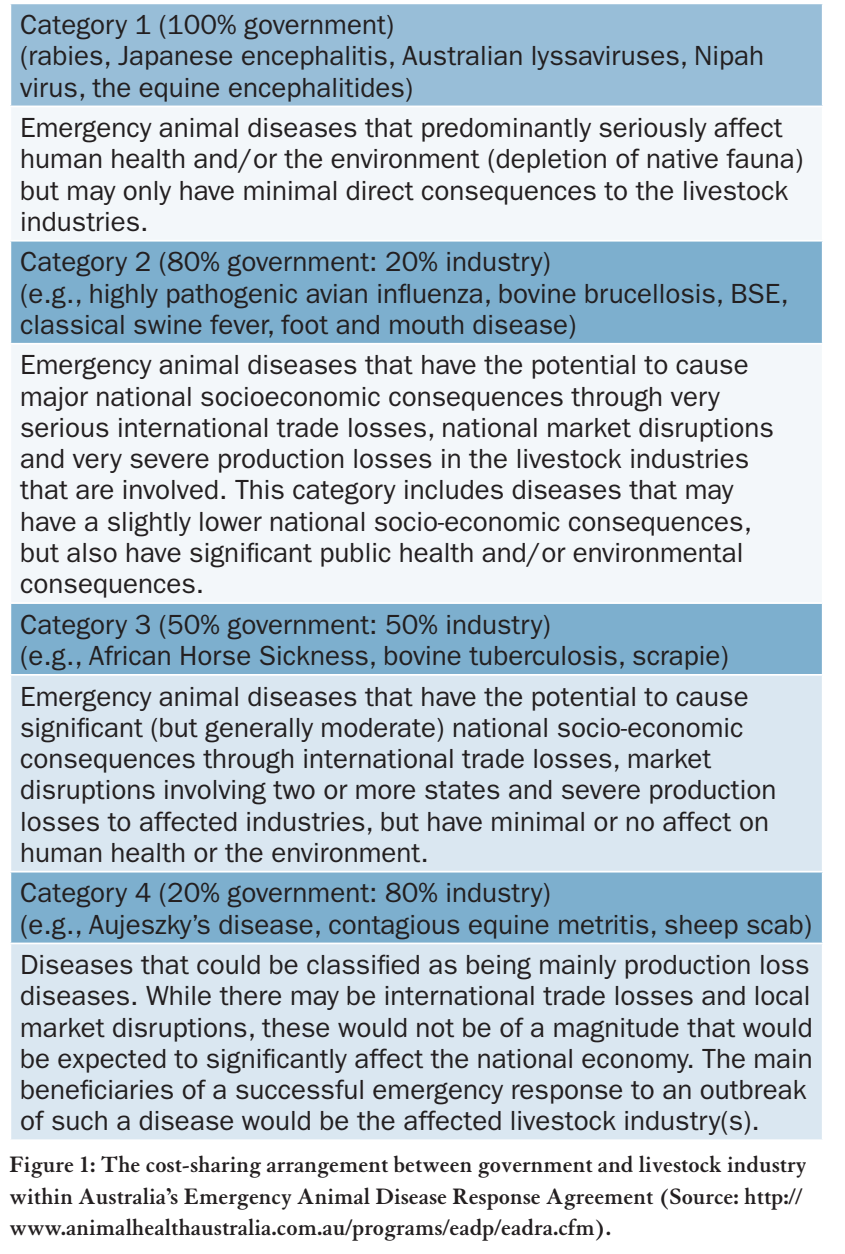

division between public and private good. As one example, it is the responsibility of Dairy Australia (an industry body), and not government, to help "the (national) dairy industry to be collaborative, innovative, sustainable and competitive against both international dairy industries and substitute products". This organisation is funded entirely through industry levies, apart from government contributions (with government matching industry funds on a 50:50 basis) to research and development.

There are substantial constraints on the use of EU and national government funds to support the national animal health services in the Netherlands. As an EU member state, these constraints are also relevant to Ireland. Three key issues are important:

- There is substantial government support (through the European Commission for Agriculture; DG Agriculture) for the agricultural sector through the common agricultural policy (Anon., 2004c). The stated aims of the 
policy are to "provide farmers with a reasonable standard of living, consumers with quality food at fair prices and to preserve Europe's rural heritage".

- Further, through the European Commission for Health and Consumer Protection (DG SANCO), the Community Animal Health Policy (CAHP) provides EU-level support for strategies to prevent the introduction of exotic diseases and to eradicate and monitor some animal diseases that are still present in some areas of the community. A strategy document for 2007-2013 was recently released (Anon., 2007e), with particular emphasis on policy coordination, the refinement of integrated risk management strategies for disease prevention and a harmonised EU framework for public-private cost-sharing (Food Chain Evaluation Consortium, 2006).

- Beyond this, support is constrained by EU competition policy, which seeks to prevent distortion of the EU internal market through unfair competition, whilst respecting international commitments through the World Trade Organization (WTO). The WTO's Agreement on Agriculture provides a negotiated framework for increased market orientation in international agricultural trade, including provisions that encourage the use of less trade-distorting domestic support policies to maintain the rural economy (Anon., 2007f). Detailed EU guidelines have been developed for the application of government support (so-called 'state aid') in the livestock sector. State aid can only be used to combat animal diseases "of concern (to) public authorities", and "not measures for which farmers must reasonably take responsibility themselves" (Anon., 2002, 2006f). These provisions may be reviewed, as part of the current CAHP review (Anon., 2006f). Provisions are made for the use of state aid in technical support and in research and development (Anon., 2000, 2006f).

These findings highlight a number of issues, which may be relevant to Ireland as it considers broadening the scope of its national animal health services. The roles and responsibilities of government in the national animal health services, and the principles underpinning this involvement, must be clearly stated. These principles should be clearly communicated to relevant stakeholders, as should the boundaries of government involvement. The involvement of government, beyond current regulatory animal health issues, is constrained by EU policy.

\section{c. Private sector involvement}

Co-management by government and industry is a key feature in the Dutch and Australian national animal health services. Under national legislation, industry organisations have national responsibility for a broad portfolio of sector-level issues, including national policy development, sector-relevant research and development; information collection, analysis and dissemination; issues management; national marketing; and international trade development. In other words, industry plays the leading role in shaping its own future. Although a range of industry organisations are involved, each has defined roles and responsibilities. In each country, non-regulatory animal health issues are essentially a remit of industry. In the Netherlands, this is primarily conducted by GD Animal Health Service; in Australia, Animal Health Australia is responsible for multisector issues and defined industry organisations (such as Dairy Australia) for single-sector issues. Strategic planning is a key feature in each country; as an example, Dairy Australia is guided by a five-year (2007-2011) strategic plan, which is translated into operational plans annually. This organisation must comply with published principles of corporate governance, and is evaluated independently every three years against both its strategic and annual operational plans and the value for money it provides levy payers (Hassall and Associates, 2006). Industry financial support, through compulsory industry levies, has evolved into a key component of centralised animal health service in each country. In Australia, the imposition of levies, and the level at which they are applied, is determined by respective industry groups. The sole role of government, through the Levies Revenue Service, concerns the administration, collection and disbursement of these monies.

These findings highlight a number of additional issues, which are of potential relevance to Ireland. Within clear limits, which are predominantly defined by international and (as relevant) EU legislation, the Dutch and Australian industries have the ability to shape their own future. The national animal health services are co-managed by government and industry, each with clearly defined roles and responsibilities. Non-regulatory animal health issues are primarily the responsibility of the private sector, in both countries with substantial technical support from appropriate organisations and people. Financial support for these activities is almost exclusively from industry, through compulsory levies. In these countries, industry structures facilitate whole-of-sector cooperation.

\section{Conclusion}

This paper has considered the role of the private sector in national animal health services, based on both theoretical considerations and country case studies. Each supports the case for increased private sector involvement in Ireland's national animal health services. Furthermore, the Dutch and Australian case studies present examples of successful partnerships between government and industry, including systems and processes to address non-regulatory animal health issues. It will be in Ireland's long-term interest to broaden the scope of its national animal health services, through increased private sector involvement, given the increasing impact of non-regulatory animal health issues in global trade.

\section{Acknowledgements}

I gratefully acknowledge constructive feedback from a range of colleagues, including Douwe Bakker, Marijke Beltman, Mary Canty, Ann Derwin, Rob Doyle, Rob 
Furneaux, Liz Lane, Joe O’Flaherty, John O’Gorman, Luke O'Grady and Francisco Reviriego-Gordejo, as well as the anonymous referees.

\section{References}

Anon. (2000). Community guidelines for state aid in the agriculture sector. Official Journal of the European Communities C28: 2-24. February 1, 2000. Anon. (2004a). Regulating better. Department of the Taoiseach, Dublin. http://betterregulation.ie/. [Online]. Accessed on September 10, 2007. Anon. (2004b). Commodity and industrial boards: a means of raising standards in industry. Social and Economic Council of the Netherlands, The Hague. http://www.ser.nl

Anon. (2004c). The Common Agricultural Policy explained. European Commission Directorate General for Agriculture. http://ec.europa.eu/ agriculture/publi/capexplained/cap_en.pdf. [Online]. Accessed on August 2, 2007.

Anon. (2005a). Annual Report 2005. GD Animal Health Service Deventer. http://www.gddeventer.com/. [Online]. Accessed on August 3, 2007

Anon. (2005b). Funding for the future. The report of the beef industry funding steering committee. http://www.mla.com.au/headerandfooter/ aboutmla/howwearefunded/funding\%2Bfor\%2Bthe\%2Bfuture.htm. [Online]. Accessed on August 3, 2007

Anon. (2005c). Annual report 2004/05, Dairy Australia. http://www. dairyaustralia.com.au/content/view/15/35/. [Online]. Accessed August 7, 2007.

Anon. (2006a). Community animal health policy 2007-2013 and thereafter. http://ec.europa.eu/food/animal/diseases/strategy/theirviews_en.htm. [Online]. Accessed on August 3, 2007.

Anon. (2006b). S.I. No. 673 of 2006. Bovine diseases (levies) regulations 2006. http://www.agriculture.gov.ie/legislation/SI2006/SI673-2006.pdf. [Online]. Accessed on August 30, 2007.

Anon. (2006c). Final report of a mission carried out in the Netherlands from January 30 to February 10, 2006 in order to evaluate official controls related to the safety of food of animal origin, in particular meat, milk and their products as well as animal welfare at the time of slaughter or killing. Food and Veterinary Office, DG(SANCO)/8146/2006-MR-Final. http://ec.europa.eu/food/fvo/index_en.htm. [Online]. Accessed on August 3, 2007.

Anon. (2006d). Position of the Netherlands on European Animal Health Policy Strategy. http://ec.europa.eu/food/animal/diseases/strategy/ theirviews_en.htm. [Online]. Accessed on August 3, 2007.

Anon. (2006e). Final report of a mission carried out in Australia from October 17 to 27,2006 in order to evaluate measures concerning bovine spongiform encephalopathy (BSE). Food and Veterinary Office, DG(SANCO)/8081/2006-MR-Final. http://ec.europa.eu/food/fvo/index_ en.htm. [Online]. Accessed on August 3, 2007.

Anon. (2006f). Community guidelines for state aid in the agriculture and forestry sector 2007-2013. Official Journal of the European Communities C19: 1-33. December 27, 2006.

Anon. (2007a). Crunch time on cost sharing. Veterinary Record 161: 705. Anon. (2007b). Social partnership. Department of the Taoiseach. http:// www.taoiseach.gov.ie. [Online]. Accessed on September 12, 2007.

Anon. (2007c). Productschap Zuivel. The Dutch Dairy Board. http://www. prodzuivel.nl/Engels/dutchdairyboard.pdf. [Online]. Accessed on 16 January 2008.

Anon. (2007d). Dutch dairy sector, Productschap Zuivel. www.prodzuivel. nl/Engels/dds2007/dutch_dairy_sector.htm. Accessed on 2 December 2007. Anon. (2007e). The new Animal Health Strategy (2007-2013): 'prevention is better than cure'. http://ec.europa.eu/food/animal/diseases/strategy/ index_en.htm. [Online]. Accessed on December 2, 2007. Anon. (2007f). The Results of the Uruguay Round of Multilateral Trade Negotiations, Annex 1A, Multilateral Agreements on Trade in Goods, Agreement on Agriculture, World Trade Organization, pp43-71. http:// www.wto.org/english/docs_e/legal_e/14-ag.pdf. [Online]. Accessed on September 4, 2007.

Ahuja, V. (2004). The economic rationale of public and private sector roles in the provision of animal health services. Revue scientifique et technique - Office International des Epizooties 23: 33-45.

Baldwin, R. and Cave, M. (1999). Understanding regulation: theory, strategy and practice. Oxford University Press, Oxford.

Bicknell, K.B., Wilen, J.E. and Howitt, R.E. (1999). Public policy and private incentives for livestock disease control. Australian Journal of Agricultural and Resource Economics 43: 501-521.

Bouma, A., Elbers, A.R.W., Dekker, A., de Koeijer, A., Bartels, C., Vellema, P., van der Wal, P., van Rooij, E.M.A., Pluimers, F.H. and de Jong, M.C.M. (2003). The foot-and-mouth epidemic in The Netherlands in 2001. Preventive Veterinary Medicine 57: 155-166.

Brückner, G.K. (2004). Working towards compliance with international standards. Revue scientifique et technique - Office International des Epizooties 23: $95-107$.

Carlsson, L. and Berkes, F. (2005). Co-management: concepts and methodological implications. Journal of Environmental Management 75: 65-76.

Egan, M.P. (2001). Constructing a European market: standards, regulation, and governance. Oxford University Press, Oxford.

Ekboir, J.M. (1999). The role of the public sector in the development and implementation of animal health policies. Preventive Veterinary Medicine 40: $101-115$.

Food Chain Evaluation Consortium (2006). Evaluation of the Community Animal Health Policy (CAHP). 1995-2004 and alternatives for the future. Final Report (Part I: Main report; Part II: Pre-feasibility study on options for harmonised cost-sharing schemes for epidemic livestock diseases), European Commission. http://ec.europa.eu/food/animal/diseases/strategy/ final_report_en.htm. [Online]. Accessed on August 3, 2007.

Hardiman, N. (2002). From conflict to co-ordination: economic governance and political innovation in Ireland. West European Politics 25: $1-24$.

Hassall and Associates (2006). Three-year review of Dairy Australia, summary report. In association with Dr Bernie Bindon, Peter Frawley and Dr Bruce Standen. http://www.dairyaustralia.com.au/content/ view/346/296/. [Online]. Accessed on August 7, 2007.

Holden, S. (1999). The economics of the delivery of veterinary services. Revue scientifique et technique - Office International des Epizooties 18: 425439.

International Trade Centre UNCTAD/WTO (2005). International Trade Statistics 2001-2005. http://www.intracen.org/tradstat/welcome.htm. [Online]. Accessed on August 16, 2007.

Kalis, C.H.J., Collins, M.T., Barkema, H.W. and Hesselink, J.W. (2004). Certification of herds as free of Mycobacterium paratuberculosis infection: actual pooled faecal results versus certification model predictions.

Preventive Veterinary Medicine 65: 189-204.

Knill, C. and Lenschow, A. (2003). Modes of regulation in the governance of the European Union: towards a comprehensive evaluation. European Integration online Papers (EIoP) 7. http://eiop.or.at/eiop/texte/2003-001a. htm. [Online]. Accessed on September 10, 2007.

Lehane, R. (1996). Beating the odds in a big country: the eradication of bovine 
brucellosis and tuberculosis in Australia. CSIRO, Melbourne.

Leonard, D.K. (2004). Tools from the new institutional economics for reforming the delivery of veterinary services. Revue scientifique et technique - Office International des Epizooties 23: 47-57.

Martin, P.A.J., Cameron, A.R., Barfod, K, Sergeant, E.S.G. and Greiner, M. (2007a). Demonstrating freedom from disease using multiple complex data sources 2: Case study —Classical swine fever in Denmark. Preventive Veterinary Medicine 97: 98-115.

Martin, P.A.J., Cameron, A.R. and Greiner, M. (2007b). Demonstrating freedom from disease using multiple complex data sources 1: A new methodology based on scenario trees. Preventive Veterinary Medicine 97: 71-97.

McCarthy, J. (2007). Why eradicate IBR and BVD in Ireland? Irish Farmers Journal, March 17, 2007. http://www.farmersjournal.ie/2007/0317/ farmmanagement/beef/feature.shtml. [Online]. Accessed on December 2, 2007.

McGuinness, M. (2004). Future shape of Teagasc to be decided this week. Irish Independent January 6, 2004.

More, S.J., Collins, J.D., Gormley, E., Good, M., Skuce, R. and Pollock, J.M. (2006). Special issue: $4^{\text {th }}$ International Conference on Mycobacterium bovis. Veterinary Microbiology 112: 89-394.

More, S.J. (2007). Shaping our future: animal health in a global trading environment. Irish Veterinary Journal 60: 541-549.

More, S.J. and Good, M. (2006). The tuberculosis eradication programme in Ireland: A review of scientific and policy advances since 1988. Irish Veterinary Journal 112: 239-251.

Pomeroy, R.S. and Berkes, F. (1997). Two to tango: the role of government in fisheries co-management. Marine Policy 5: 465-480.

Radunz, B. (2006). Surveillance and risk management during the latter stages of eradication: Experiences from Australia. Veterinary Microbiology 112: 283-290.

Room, G. (2005). Policy benchmarking in the European Union: indicators and ambiguities. Policy Studies 26: 117-132.

Sen, A. and Chander, M. (2003). Privatization of veterinary services in developing countries: a review. Tropical Animal Health and Production 35: 223-236.

Sheahan, M., O'Hagan, G., Power, S. and Kenny, K. (2006). Brucellosis in cattle in Ireland 1998-2005: Progress towards eradication continues. Irish Veterinary Journal 59: 217-221.

Sheridan, H. A., McGrath, G., White, P., Fallon, R. Shoukri, M.M. and Martin, S.W. (2005). A temporal-spatial analysis of bovine spongiform encephalopathy in Irish cattle herds, from 1996 to 2000. Canadian Journal of Veterinary Research 69: 19-25.

Shillhorn van Veen, T.W. and de Haan, C. (1995). Trends in the organization and financing of livestock and animal health services. Preventive Veterinary Medicine 25: 225-240.

Treib, O., Bähr, H. and Falkner, G. (2007). Modes of governance: towards a conceptual framework. Journal of European Public Policy 14: 1-20.

Umali, D.L., Feder, G. and de Haan, C. (1994). Animal health services: finding the balance between public and private delivery. The World Bank Research Observer 9: 71-96.

Weber, M.F., van Roermund, H.J.W., Vernooij, J.C.M., Kalis, C.H.J. and Stegeman, J.A. (2006). Cattle transfers between herds under paratuberculosis surveillance in the Netherlands are not random. Preventive Veterinary Medicine 76: 222-236.

Whittem, J. (1998). Book review (Beating the odds in a big country: the eradication of bovine brucellosis and tuberculosis in Australia). Australian Veterinary Journal 76: 701. 